\title{
Social Entrepreneurship and Communication for Development and Social Change Rethinking Innovation
}

\author{
Emile G. McAnany ${ }^{1}$
}

\begin{abstract}
This article argues that social entrepreneurship has not yet been adequately defined even though it is increasingly being used in social change/development practice. Muhammad Yunus, creator of the Grameen Bank and microlending, and Bill Drayton, founder of the global change agency Ashoka, have practiced social change through social entrepreneurship for more than 30 years. Increasingly, the development community has been adopting many of its practices. The basic process of social entrepreneurship involves: defining a social goal for the solution of a serious problem; innovation in solving the problem; ability to expand the organization to serve large numbers of people (scaling up); focusing on the social bottom line with empirical evidence (impact evaluation). Three cases are briefly reviewed to illustrate this process. Finally the article examines how these practices might help Communication for Development (C4D) to better adapt its own practices in achieving real change with people.
\end{abstract}

Keywords: social entrepreneurship, Grameen, Ashoka, C4D, innovation, impact

\section{Introduction}

Although the term is not used much in the field of Communication for Development and Social Change (C4D), social entrepreneurship as a concept has a history and a pedigree in other development discourses. David Bornstein and Susan Davis (2010) define three historical phases that the idea has passed through in the last three decades. The first phase was to "identify people with innovative ideas and practical models for achieving major social impact," spotlight their work and provide a support system. The second phase was to help social entrepreneurs build sustainable and high impact organizations through better processes of management, finance and outcome evaluation. The focus at present, in the third phase, is to help promote all people as potential change makers in whatever form that someone can manage, much more in the style of a social movement. (ibid: $x x$ )

The pedigree for the idea derives from three organizations that provided the successful early practice of the concept over three decades: the Grameen Bank and the Bangladesh Rural Advancement Committee (BRAC) in Bangladesh and the USA-based Ashoka organization. Beginning in the late 1970s in Bangladesh, Grameen and BRAC helped 
to organize millions of the poor. Ashoka, founded in 1980, helped to identify people on the ground who had already begun promising social change projects, and provided them with interim support as they attempted to scale their work to reach a critical mass.

We are in a stage where different efforts to theorize social entrepreneurship have only begun. Ashoka's founder Bill Drayton proposed the term "social entrepreneur" just as Grameen had popularized the term "micro-lending." Even though the latter gained widespread popularity in the 1990s, "social entrepreneur" lagged behind in the social change discourse until the beginning of the new millennium. The work of defining and beginning to theorize social entrepreneurship really only appeared in writing in the last ten years (Dees 1998, Nichols 2006, Bornstein 2007, Martin and Osberg 2007, Bornstein and Davis 2010). The other factor that has promoted the definition of the term is the practice of foundations like Skoll ${ }^{2}$, Echoing Green ${ }^{3}$ and the Geneva-based Schwab Foundation for Social Entrepreneurship ${ }^{4}$, which have funded and helped to defined practice over the last decade.

But what might this relatively new development discourse have to do with C4D?

\section{Communication for Development and Social Change: Historical Perspective}

The idea of using communication for development and social change is almost 60 years old, and there is a certain amount of common agreement concerning its historical contours. Three phases can be identified.

The earliest approach was called "development communication" and relied on the twin theories of modernization and diffusion based on writings of Daniel Lerner, especially his classic The Passing of Traditional Society: Modernizing the Middle East (1958) and Everett Rogers' Diffusion of Innovations (1962 $1^{\text {st }}$ edition). Added to this was Wilbur Schramm's policy prescription, Mass Media and National Development: The Role of Information in the Developing Countries (1964) as the third of what some call the "founding fathers" of the field. These books formed the theoretical foundation on which UNESCO was to develop its expanding practice of C4D in the 1960s (McAnany 2012).

The other two approaches or paradigms in this history are also agreed upon, though their dates and interpretations vary somewhat. In the late 1960s the critical or dependency paradigm concerning development and social change began to gain momentum in Latin America (Frank 1969; see Cardoso and Faletto 1969 for more general theory). The connection with media and communication was not far behind (Freire 1970, Dorfman and Mattelart 1971, Gerace 1973). To this was added a critique of the original modernization-diffusion paradigm of C4D (Golding 1974, Rogers 1976 adds a self-critique). This critical paradigm sometimes overlaps with the third approach of participation, but again the distinction between the two is often open to disagreement (see Sparks 2007, who argues for two forms of participatory theory, one critical, the other not). The importance of the third approach, of participation, is that its focus on peoples' role in their own development is reminiscent of Freire and downplays to some extent the role of communication technology (Servaes 1989, Jacobson 1985, Dervin and Huesca 1994).

Beyond these three paradigms, there has been new theorizing over the last two decades, including the work of Singhal and Rogers on entertainment education (1999, and Singhal, Cody, Rogers and Sabido 2004), but such work does not qualify as a paradigm. 
In much of the general literature, the participatory approach has sometimes been classified as a throwback to the earlier modernization-diffusion paradigm with a top-down focus that undermines genuine participation (Huesca 2003). Thus, despite continuing applications of C4D, the field seems stalled in terms of new theoretical or broad policy initiatives to meet the needs of the poor in the new millennium.

As this millennium began, the United Nations saw an opportunity to redefine the needs for social change on a global basis. The Millennium Development Goals (MDGs) were eight broad initiatives for reducing poverty, discrimination and inequality while promoting better health, education, employment and nutrition for the majority populations in many countries. The advantage of this initiative was that the goals were stated with specific metrics and with defined deadlines. The specificity helped apply clear and constant measures of the achievement of goals in an ongoing manner, with annual reports that called attention to meeting specific goals ${ }^{5}$. The other advantage of the MDGs was a general consensus by UN members in 2000 that these goals were urgent necessities that could help generate continued international support. The occurrence of 9/11 in 2001 probably hurt such momentum, but the restatement of the goals and the adjustment of the specific levels of achievement in 2005 indicated a still strong backing by member nations.

The other contextual factor that began to emerge especially in this decade was the rise of China, India and Brazil as economic growth centers. This made the designation of "developing countries" more complex and ushered in thinking that suggested that some of the stereotypes of past development theory needed to be questioned.

\section{Social Entrepreneurship as a Paradigm for Development?}

As outlined above, the practice of social entrepreneurship is not recent. Its roots go back to the 1970s, when applications of social organizing took root in Bangladesh without the benefit of theory. In what is now part of the "creation myth" of the idea of microlending and microfinance, Muhammad Yunus (1999) recounts how during a severe famine in his country he and some of his economics students at a university went out to distribute small amounts of money to surrounding villages as unsecured loans and found an astoundingly high level of repayments. This grew from a handful of recipients in 1974 to 7,000,000 by 2007, and the establishment of a large set of institutions that did everything from telecommunications to manufacturing of yogurt as well as acting as a bank for the poor (Yunus 2007). A similar history of growth and success is the parallel history of BRAC, also in Bangladesh. The kind of organizations that BRAC and Grameen represented were different from usual development efforts at that time, and the difference suggested an innovation in thinking about development and social change.

Theories of C4D seem more robust when they are built from practice. However, Bill Drayton, the founder of Ashoka, did not begin with a carefully parsed theory, but rather a pragmatic understanding of how three things in his background came together for an insight into how significant change might be achieved in practice: his understanding of the historical context of the industrial revolution in the forms of western business expansion from the $18^{\text {th }}$ through the $20^{\text {th }}$ centuries; the organizational structures and malfunctions of government services; and a focus on developing areas by his early travels to India. His premise in creating Ashoka was that the way social services could 
be brought to the masses, whether in the USA or in developing countries, needed to be completely rethought. Drayton did not want to work within existing structures, which he found to be unwilling or unable to change (he had worked as a consultant with McKinsey and in the Carter administration's Environmental Protection Agency). He wanted to find people who had an idea for change that had shown proof of concept on the ground and in practice and who with some initial financial, and later social, support could expand the work to more people. Thus, Ashoka began to recruit people to the organization that did not dictate a single solution nor promise long term financing, but promised ongoing professional support to help turn the idea into a standalone organization that would create social benefit for more and more people.

There were some characteristics that Ashoka looked for in their recruitment of these change makers whom they would support, which suggest a vision of social change. These were:

- creativity/social innovation: a new and original idea about how to solve a significant social problem that had been field tested;

- entrepreneurial quality: someone attuned to a particular context and not satisfied until their idea works locally and is spread to as many people in the region or nation as possible (sometimes termed "scaling up" in development terminology);

- social impact of the idea: two aspects of the idea are included: the idea has some kind of measureable impact (not necessarily quantitative - more below on this) and it is adopted by others in different contexts for application and spread (replication);

- ethical fiber: the change maker inspires trust in others (a concept so important in Drayton's mind, that a unanimous vote was required by the interviewing group ) (Bornstein 2007).

What this means for recruitment of new members of Ashoka fellows is that their ideas are innovative, that they demonstrably solve an important social problem and that they are driven to reach as many people as possible and are trusted by their peers. There is no narrow framework of an "Ashoka" approach, no ideology or specific theory of change, nor an expectation of continued financial support. What is implicit in the work of fellows is that some kind of organization will be built to carry on the work as it expands, again without designating what that structure should be. Nor did Drayton define what elements the resulting organization should have, except the need to define the mission and to provide for its growth and its sustainability over time by securing resources, attracting collaborators and appealing to an audience by its service. This was not a definition of social entrepreneurship in an academic or theoretical sense, but a blueprint for application. Others would later try to sort out the meaning.

\section{Defining Social Entrepreneurship: Theory and Practice}

The work of Yunus was recognized early on as successful application of a basic element of economic growth: providing finance so people could invest in a business and create jobs. The originality of his idea as he suggested in his 1999 book, Banker to the Poor, was making very small, unsecured loans to poor people, a concept that came to be called microlending or later microfinance. More than just an innovative idea, Yunus 
helped create a large organization in Bangladesh over several decades, reaching millions of poor people, many of whom were able to emerge from poverty. He became not only a recognized voice in development circles but a trusted figure at the head of the largest loan organization in Bagladesh. In short, he fulfilled the criteria of Drayton's recruitment process and would later himself adopt the term of social entrepreneur. Thus, these two figures defined the practice of the concept before it began to be defined by academics in more abstract terms.

That some business schools should take up the issue of social entrepreneurship does not seem surprising because of its relationship to economic entrepreneurship. In a recent discussion of how social entrepreneurship differs from the original business meaning of the term, Martin and Osberg (2007) make some distinctions that may be useful to keep in mind. They describe a social entrepreneur as "someone who targets an unfortunate but stable equilibrium [in society] that causes the neglect, marginalization or suffering of a segment of humanity; who brings to bear on this situation his or her inspiration, direct action, creativity, courage and fortitude; and who aims for and ultimately affects the establishment of a new stable equilibrium that secures permanent benefits for the targeted group or society at large" (ibid: 39 ). The example of Yunus comes to mind. But also, on a smaller scale, is the work of Victoria Hale, whom the authors mention as a current example of innovative social thinking. She created the organization of One World Health as a non-profit pharmaceutical company that develops new drugs for under-treated diseases in developing countries; or, as another strategy, to persuade other large for profit drug companies to let her company license their drugs to be manufactured in those countries at much lower costs ${ }^{6}$. Martin and Osberg emphasize the elements that make for a successful social entrepreneur: inspiration, creativity, direct action and courage with the result of a transformation of an unjust social situation. Transforming drug development as a social rather than a commercial enterprise is the example of creative thinking.

The other thing they mention is that the context is critical and that the change agent recognizes the opportunity within a given context to take action. But this abstract description does not do justice to the practice that can be found in cases studies where genuine social impact may be long drawn out, and large scale social transformations rare. Let us look at some cases that help illustrate both the theory and the practice to see how the best examples of such change can work.

\section{Evidence for Impact: Case Studies of Social Entrepreneurship}

The point of social change projects is that they bring about change, but the challenge is to demonstrate change as a result of project efforts. The C4D field does not have a strong record of demonstrating change or impact; in fact, the record indicates that in many cases projects do not work (Rogers 1976 and Hornik 1988 for C4D; Easterly 2006 for development at large). Social entrepreneurship as an approach has only gotten recognition in the past few years as a part of the more general development debate, and one of its fundamental criteria for the debate is its focus on impact. Part of this is due to its heritage from business entrepreneurship, where the financial bottom line is a primary focus. In business, the process is straightforward and sometimes brutal: if a business does not make a profit, it will quickly disappear - all effort is translated into a simple 
monetary metric of profit. But what is the equivalent metric in social projects? This problem has not been resolved. However, a number of social entrepreneurial projects have been working on it in the last few years.

This suggests that looking briefly at some sample cases might be a good way to go about understanding success in this approach. Since I have been a judge in a competition of social entrepreneurial projects for the last decade, I will draw upon the competition's database $^{7}$ for some examples that illustrate both the varied nature of projects and their methods of evaluating success.

Witness: this project won an award at the Technology Benefitting Humanity competition in 2003 (STS Nexus, 4, 2003,1, 25-26). It is a human rights advocacy group founded by the musician Peter Gabriel in 1991 that became an independent non-profit in 2001. The innovative idea that created it was Gabriel's conviction that the then new technology of hand held video cameras might "show" the world cases of human rights abuse on television and thereby help stop the abuse through outside pressure. But the context had changed by 2001, and Witness took advantage of another technology as the Internet became widely available. Witness grew through a new way of looking at existing opportunities to confront human rights abuses; in other words, it fulfilled the first criteria of social entrepreneurship, innovative thinking. And it did so twice within a decade. The organization, however, did not define itself by technology but its peopleto-people strategy. Early on it began to see that simply handing out video equipment to a variety of organizations was less productive than promoting a deeper change through the choice of a few organizations with whom to work on a longer term and in depth basis of three years of training, not only in the use of technology but also in organizing a planned approach that would include technology, human rights law, careful planning and a focus for each campaign that an organization might carry out. This illustrates another facet of social entrepreneurship: planning and management. Finally, Witness has demonstrated over more than one decade the ability to sustain itself financially by appealing to foundations and individual donors with clear goals and a strategy for achieving those goals, plus clear evidence of impact and effectiveness made available to supporters and the general public. The evidence of this is carried to the public via a sophisticated website. The site contains semiannual reports, a cache of thousands of hours of video documentation, a list of successes in pursuing court cases against abusers (where the videos are an important form of evidence) and ways that their associates' campaigns have not only stopped abuses and sent abusers to jail, but sometimes even changed social policy.

Datadyne/EpiSurveyor: this social business "creates web and mobile software to benefit NGOs, governments, researchers and businesses worldwide" (datadyne.org) and operates in Chile, Kenya and the USA. It was created in 2003 by a Center for Disease Control (CDC) epidemiologist who saw the need for better health data collection in the most remote regions of developing countries. Since its founding, the organization has grown rapidly and now serves 3,000 clients in 160 countries. Its primary technology is its EpiSurveyor software which allows survey data to be collected on cell phones even where there is no network and later to be uploaded to a computer for analysis and application to critical decisions for projects. This is a free service to anyone who 
needs it. In 2009, a commercial service was added that costs $\$ 5,000$ a year and acts as a cross-subsidy for the $99 \%$ of users who get the free but less sophisticated service. DataDyne is essentially a software consulting business with a special focus on rural health care, but EpiSurveyor is used for many other purposes of data collection by NGOs in areas where survey data can be useful for the specific mission of each organization. Several observations about this particular organization as a social enterprise are of interest. First, DataDyne is a social business in one important aspect: in 2009, it decided to begin to sell a more advanced service to paying customers in order to eventually free itself from dependence on foundations and government grants. It hopes to be self-financing in the near future, but $99 \%$ of its users receive its original service for free and will continue to do so. Second, one of the reasons that the founder, Joel Selanikio, started this organization was that he saw that working directly with larger organization like the CDC or ministries of health in other countries were bogged down by bureaucracy and sometimes corruption so that important data were late or were not used at all. DataDyne works with all kinds of organizations, large and small, in ways that can eliminate some of the bureaucratic barriers and provide timely data. Third, with a focus on field work and a recognition in 2003 that the simple cell phone was becoming an important data collection tool, EpiSurveyor was able to serve an important health care purpose. As it turned out, the software was quickly applied to many other development tasks (replication of the innovation). As cell phone innovation spreads and more sophisticated software and hardware spread to many areas, DataDyne should be able to adapt to these changes in technology and continue to bring their free services to users who need them.

A Single Drop for Safe Water (singledrop.org), based in the Philippines, has over the past five years helped to create safe drinking water and sanitation systems in a number of communities in the southern territory of Mindanao. The approach is to work with small communities to help guide them in creating water and sanitation systems that the community plans and executes with the help of Single Drop (participation by people) which provides training in planning, implementation and monitoring so that the system can continue to function under community control. Single Drop also helps find funders. What is special about their approach is that the community must gain the support of the people there because they will ultimately be responsible for the implementation of the project as well as creating a self-financing system to continue its functioning after the system is created. What Single Drop does is help the community to go through the process of deciding if clean water and better sanitation is something they really want. The truth is that in many areas, governments do not supply clean water to people. The work of Single Drop is to provide advice and help with original funding, but it is up to the local community to continue the system. Single Drop continues to monitor and help the systems function properly. It has helped 140,000 people get safe water and better sanitation in 31 municipalities in the Philippines, and is now also beginning work in Uganda. The innovation that Single Drop brings to the problem is that it operates as a consultancy to communities applying for help and works to monitor the system to see that it is working well over time. But it does not itself implement nor fund the project. People create and operate their own system that is demand driven, not as in most cases supply driven by funders looking for projects to start. 
What this project shows are several lessons in social entrepreneurship. First, water as a sector of development is identified as a critical part of poor peoples'lives and welfare. Second, the project lets communities decide that clean water/sanitation is something they want (not what a funder decides is important for them). Moreover, with the help of initial funding, each community is responsible for building, operating, financing and maintaining the system themselves with a variety of approaches, funding mechanisms and governance structures that they feel are appropriate. Single Drop helps communities with advice and feedback on the ground. By letting communities decide and take responsibility for their own development, a form of community empowerment is fostered.

What do these few cases suggest about social entrepreneurship? If the key elements of the concept are creativity/social innovation, entrepreneurial drive/scaling, social bottom line/impact, sustainability and replication, then these examples help us to make some conclusions about this approach/paradigm.

First, each of these examples represents an innovative approach to solving a significant social problem. Second, all have shown their ability for expansion to more people, or 'scaling up'. Third, each has demonstrated its ability to assess impact with a variety of data. Fourth, each has built an organizational structure that not only has scaled up but has managed to adapt to contexts, to technologies, and to funding sources for sustainability. Each is demand-driven, where the growth comes from defined needs of people, not supply-driven outside aid. One final comment, none of the projects was created by large aid-giving institutions. They originated from one person seeing a problem and trying to solve it in a new way in a local context. The local organization can grow and scale up, but the idea can also be replicated by others and new organization can grow in different contexts.

The question at this point is whether all of this in any way relates to the C4D tradition of the past 60 years.

\section{C4D and Social Entrepreneurship: Can there Be a New Paradigm?}

In this article I argue that there is a fourth paradigm that has begun to emerge in general development policy and practice, if not in carefully defined theory. Having tried to define and explain the approach as it has developed in the past two decades, I will in what follows explore how social entrepreneurship might be useful in the work of C4D in the coming decade.

There are some questions that need to be addressed. Social entrepreneurship as a practice or a policy approach does not focus on communication as a basic premise of its work as C4D does. So how would this help C4D? There are two ways to look at this question. First, if C4D is a development practice, it can benefit from a variety of ways to promote and to improve that practice. The three historical paradigms mentioned above suggested different ways to achieve this goal. Social entrepreneurship is no different. It is a set of integrated practices that stress certain aspects of organizing field work: social innovation, scaling, attention to management/finance practices, monitoring results and replication by others. There does not seem to be a contradiction between what C4D has traditionally done on the ground and what this new approach suggests. Second, there are already a number of social enterprises operating in the area of communication and ICTs 
(McAnany 2012, and 2006), even though the application of social entrepreneurship is much broader than the interpersonal and mediated communication of C4D. But this does not mean that the principles of this approach are not useful for C4D practice and theory.

The more serious question, perhaps, is about funding sources. As we have developed the arguments in this article, it is clear that social entrepreneurship as it is successfully practiced does not or cannot depend on large institutional funding over a long period. The reasons for this are too complex to detail here, but the general concept of entrepreneurship suggests that the innovative work of social change must begin locally and grow locally to meet some local unmet need. The funding, if it is not to stifle the innovation, must be under the control of the creator of the social innovation. Funding is necessary, but it is to help and not to direct. Four stories of people working in development over many decades have recently been published that suggest the nature of the problems with large scale institutional funding for development (Fraser and Restrepo-Estrada 1998, Quarry and Ramirez 2009, Easterly 2006, Moyo 2009). Each story is unique to the teller (the first four authors worked in C4D, while the latter two are experts in development economics), but the thesis is similar: big aid-giving institutions have a difficult time achieving real change for people on the ground. When large institutions sponsor projects, their bureaucracy often hinders or even undermines the work of genuine change. The social entrepreneur tries to seek funding that she controls, so that the growth of the enterprise responds to the needs on the ground and not to those of the funding institution (see McAnany 2010).

The experience of C4D over the decades has often been with the large aid-giving institutions. In that sense, adopting the social entrepreneur paradigm would be a major shift. It is clear to the critics of large institutional aid that this kind of funding will not disappear any time soon. What this may mean for the social entrepreneurship approach is that either the large institutional funders change their practices, which seems unlikely, or recipients think carefully about how to seek funding in a way that keeps the control in their own hands. In this case, small seems better than large: a number of smaller sources makes a project less dependent on any one source An appropriate funding strategy is a key concern of a social enterprise but has not figured much in C4D theory or practice.

Another key factor in social entrepreneurship is social innovation. In C4D, the focus on innovation over the decades has been on new communication technologies. If we examine the efforts of organizations like the World Bank, the UN special agencies or bilateral government organizations, it seems that most often projects grow out of some new communication technology that is seen as a "solution" to a development problem. Television in the 1960s was going to empower the great push for education in developing countries; communication satellites in the 1970s were going to help a variety of countries to solve problems in rural areas where satellites could supply telephones to isolated towns; the Internet could help solve health problems; now social media can help make great political changes in the current Arab Spring. The mistake has been that these tools have been deployed widely without consideration for the people who might use them. If there are benefits in the uses of technologies, they are that people can appropriate them for their own purposes depending on local contexts.

The issue of scale is one that has plagued C4D for decades. There are few projects that have created widespread benefits for people over long periods of time. The Latin American Radio Schools ${ }^{8}$ began with one radio transmitter in Colombia in 1947 (Fraser and Restrepo-Estrada 1998) and spread throughout Latin America because of a strongly 
felt need on the part of local groups. But this is an exception, which took place under special circumstances. The more common experience is that an interesting communication experiment with initial success will fail to grow (such as e.g. India's Radio Farm Forums or Basic Village Education in Guatemala) because local priorities were different from those of the large outside funders.

For any social innovation, the answer to scaling up is twofold: demand on the part of participants (where the service or product serves a felt need) and the ability of the local organization to include serious thinking about expansion as part of an organizational plan and to keep in touch with participants and their needs. This final point leads to another element in the new paradigm, i.e. outcome monitoring.

Evaluation of outcomes has been a part of C4D from the beginning, but it has been implemented only sporadically and more often as a need of the funder than of the project. Social entrepreneurship has a more internally oriented need to know about outcomes. There is a built-in need to know whether a project is continuing to achieve its own purpose for its participants as planned. This may be the ideal, but even the best social enterprise has difficulty in tracking outcomes or benefits on a regular basis for several reasons. First, even if the project has clearly stated goals, the ways to track their achievement is not easy or straightforward. For profit enterprises have the relatively simple metric of financial profit. Social enterprises often have to assess more intangible social benefits like education, health, nutrition or agricultural productivity.

C4D also has had difficulty in deciding what kinds of evidence could demonstrate success, even when money was available for such work. The problem of doing regular monitoring and evaluation is a challenge, especially in small projects. Sometimes the motivation for this kind of effort may come from outside funders who demand some accounting for project success, with the added complication that the funder often defines success in terms of their own institutional goals, not those of the project participants. There are ongoing efforts to think about this and collect different strategies by C4D organizations like the Communication Initiative ${ }^{9}$ that might help. Similar efforts have been part of Ashoka and Grameen from their beginnings. But the problem of outcome assessment for C4D is probably similar to that experienced by social entrepreneurial ventures. The only advantage of the latter, perhaps, is that the need for this evidence is more clearly focused from the outset.

\section{What Are the Downsides to this New Approach?}

While this article argues in favor of considering social entrepreneurship as a useful paradigm for communication for social change to adapt, I want to make clear that I do not see this approach as a panacea. I do however think that its practice and the thinking behind it might benefit C4D as it proceeds into the next decade. I will outline a few concerns at this point that those who wish to explore this approach might keep in mind.

First, the term social entrepreneurship is becoming so popular among some working in development that it can become a fad rather than a serious undertaking. There are stories of quick successes (the social startup Kiva (kiva.org) raised $\$ 100$ million in its first four years as an online fundraiser for microfinance agencies around the world) that suggest almost a magic solution to long term problems like poverty. Silicon Valley, where I live, is awash with big success stories that are deceptively simplistic in their 
presentation to the public. The answer to this is that even the most creative idea must have someone behind it who works hard to make even small progress.

Second, the hype about social entrepreneurs can make them into modern heroes. Sometimes they are, but the truth is that even the best, like Mahammad Yunus, can be accused of wrongdoing (he was not allowed to continue as head of Grameen because of recent political accusations by government officials). There is always plenty to critique in this approach, and even the best social entrepreneur can make mistakes and must reposition a project without giving up the goal.

Third, there has been criticism of this approach because it seems to emphasize the organization over its ultimate users. This has been a key objection by some who see this as deflecting the focus in development and social change away from people and onto technology and organizational structure. The response to this is more complicated than I can deal with here, but I should remind readers that the ideal social enterprise has to be focused on the beneficiary or it cannot succeed. To its credit, the C4D paradigm that emphasizes participation has made this explicit, but the elements of the organizational structure of social entrepreneurship add to this strength.

Finally, the emphasis of social entrepreneurship on finance and management practices makes it seem like a business and this has negative connotations for many working in development. There is no simple answer except to say that some of the practices of business may be beneficial for adaptation by those who have a different goal for their organizations, a social goal whether it be better health, social justice, combating poverty or changing a social system.

\section{Conclusion}

The discussion so far has indicated how C4D and social entrepreneurship as development and social change endeavors might overlap. To conclude, I will briefly examine how a more consistent effort of C4D to adapt aspects of social entrepreneurship might benefit its practice. First, concerning funding sources, it does not seem likely that large aid institutions will change funding patterns in the near future unless members of the C4D tradition, academics, policy makers and people on the ground push for change within and outside institutional boundaries. As more and smaller innovative projects emerge from countries like India, Mexico, Brazil, Indonesia, etc., how will interested academics and policy makers keep in touch with these developments? Ashoka has made a beginning with its almost 3,000 fellows that are not only accounting for their own individual projects, but are also beginning to collaborate on collective efforts within major development sectors like energy and health (ashoka.org provides much material). Academics and policy makers need to develop strategies for finding and collaborating with social innovators on the ground with new ideas about solving old problems. Here is where newer search technology for the web will help. Ashoka and the Skoll Foundation are two sources for a great deal of information about small projects around the globe; also the Communication Initiative for communication based projects and the Center for Science, Technology and Society at Santa Clara University (scu.edu/csts/education) for recent social enterprises.

Innovation in $\mathrm{C} 4 \mathrm{D}$ has often been driven by the communication technologies that have emerged. That may not entirely change with a new paradigm, but C4D as a field needs to find how these new technologies are being implemented in ways that respond 
to peoples' real needs on the ground. Academics have a role in the analysis of projects in ways that help sort out more general processes at work that can be adapted to other contexts as well as developing more general theory. This is how replication can best be fostered: sharing innovative ideas across contexts by not only making information available on the Internet, but by thinking of how to adapt ideas to different contexts (cultural, social, political and economic). Again, this is a task for academic and policy research in $\mathrm{C} 4 \mathrm{D}$ as well as borrowing from recent social entrepreneurship experience.

The paradigm of social entrepreneurship is being defined by a large number of small, innovative projects around the world. The parameters of its practice are becoming clear. Now that there is a large accumulation of experience, someone needs to begin building a theory that might join both the older tradition of C4D with the newer approach of social entrepreneurship. The opportunity is there for C4D to rethink its own practice.

\section{Notes}

1. Emile McAnany is Professor in the Department of Communication at Santa Clara University, California in the US. E-mail: emcanany@scu.edu.

2. See skoll.org

3. See echoinggreen.org

4. See Schwabfoun.org

5. Unlike the often-declared "decades" initiatives (e.g. decade for development in the 1960s) of the UN with a focus on one or other general goal and an assessment at the end that most often came up short.

6. See oneworldhealth.org

7. See scu.edu/csts/education for a list of finalists over eleven years.

8. See aler.org

9. See comminit.org

\section{References}

Borntsein, D. (2007) How to Change the World. New York: Oxford University Press.

Bornstein, D. and S. Davis (2010) Social Entrepreneurship: What Everyone Needs to Know. New York: Oxford University Press.

Cardoso, F.H. and E. Faletto (1979) Dependency and Development in Latin America. Berkeley CA: University of California Press (Portuguese edition 1969).

Dees, G. (1998/2001) “The meaning of 'Social Entrepreneurship"” www.fuqua.duck.edu/centers/case/documents/Dees_SEdef.pdf

Dervin, B. and R. Huesca (1999) "Participatory Communication and Development Narrative: An Examination of the Meta-Theoretical Implications and their Impacts.” In T. Jacobson and J. Servaes (eds.) Theoretical Approaches to Participatory Communication. Cresskill,NJ: Hampton.

Dorfmann, A. and A. Mattelart (1975) How to read Donald Duck: Imperial Ideology in the Disney Comic. New York: International General, (Spanish edition 1971).

Easterly, W. (2006) The White Man's Burden: Why the West's Efforts to Aid the Rest has Done so Much Ill and so Little Good. New York: Penguin Press.

Frank, A.G. (1969) Underdevelopment or Revolution: Essays on Development of Underdevelopment and the Immediate Enemy. New York: Monthly Review Press.

Freire, P. (1970) Pedagogy of the Oppressed. New York: H\&R Paper Books.

Freire, P. (1975) Extension or Communication: The Conscientization of the Rural Countryside. Mexico City: Siglo XXI, 1975 (Spanish edition).

Fraser, C. and S. Restrepo-Estrada (1998) Communicating for Development: Human Change for Survival. London/New York: I.B. Tauris Publishers.

Gerace, F. (1973) Horizontal Communication. Lima: Libreria Studium, (Spanish).

Golding, P. (1974) "Media Role in National Development." Journal of Communication, 24, 39-53.

Hornik, R. (1988) Development Communication: Information, Agriculture and Nutrition in the Third World. New York: Longman. 
Emile G. McAnany Social Entrepreneurship and Communication for Development and ...

Huesca, R. (2003) "Participatory Approaches to Communication for Development" B. Mody (ed.) International and Development Communication; $21^{\text {st }}$ Century Perspective. Thousand Oaks: Sage.

Jacobson, T. (1985) "Epistemological Shift in Development Communication Theory" in B. Dervin and M. Voigt, eds. Progress in Communication Sciences. Norwood NJ: Ablex.

Lerner, D. (1958) The Passing of Traditional Society: Modernizing the Middle East. New York: The Free Press.

Martin, L. and S. Osberg (2007) "Social Entrepreneurship: The Case for Definition." Stanford Social Innovation Review, Spring, 29-39.

McAnany, E. (2009) "Incentives and Participation in Development Communication: Evidence from Sixty-three Recent Projects." Paper presented at The World Congress on Communication for Development, Rome, 2006. (Also in edited online form in Glocal Times, 13 Nov. 2009).

McAnany, E. (2010) "Communication for Development and Social Change: New Millennium." Communication Research Trends, 29, 3, pp. 3-17.

McAnany, E. (2012) Saving the World; A Brief History of Communication for Development and Social Change. Champaign IL: University of Illinois Press.

Moyo, D. (2009) Dead Aid: Why Aid is Not Working and How There is a Better Way for Africa. New York: Farrar. Strauss, Giroux.

Nichols, A. (ed.) (2006) Social Entrepreneurship: New Models of Sustainable Social Change. New York: Oxford University Press.

Quarry, W. and R. Ramirez (2009) Communication of Another Development: Listening before Telling. London/ New York: Zed Books.

Rogers, E. (1962) Diffusion of Innovations. New York: The Free Press.

Rogers, E. (1976) Communication and Development: Critical Perspectives. Beverly Hills CA: Sage.

Schramm, W. (1964) Mass Media and National Development: The Role of Information in Developing Countries. Stanford/Paris: Stanford University Press and UNESCO Press.

Servaes, J. (1989) One World Multiple Cultures: Towards Another Paradigm on Communication for Development. Leuven: Acco.

Singhal, A. and E. Rogers (1999) Entertainment-Education: A Communication Strategy for Social Change. Mahwah NJ: LEA.

Singhal, A., M. Cody, E. Rogers, M. Sabido (eds.) (2004) Entertainment-Education and Social Change: History, Research and Practice. New York: Routledge,.

Sparks, C. (2007) Globalization, Development and the Mass Media. New York: Sage.

Yunus, M. with A. Jolis (1999) Banker to the Poor: Micro-Lending and the Battle Against World Poverty. New York: Public Affairs.

Yunus, M. with K. Weber (2007) Creating a World Without Poverty: Social Business and the Future of Capitalism. New York: Public Affairs. 